\title{
Analysis of the Impact of Fiscal Policy on Economic Growth in South Africa: VECM Approach
}

\author{
Tshembhani Mackson HLONGWANE, Itumeleng Pleasure MONGALE, Lavisa TALA \\ School of Economics and Management, University of Limpopo, South Africa \\ itumeleng.mongale@ul.ac.za
}

\begin{abstract}
Fiscal policy ensures macroeconomic stability as a precondition for growth at the macro level. This study investigates the impact of fiscal policy on economic growth of South Africa from 1960 to 2014 through a Cointegrated Vector Autoregression approach. It seeks to contribute to the existing literature as well as in designing effective fiscal policy programmes which can propel economic performance. Theresults of the long run estimates revealed that government tax revenue has a positive and significant long run influence on economic growth, whereas the government gross fixed capital formation and budget deficit have a negative impact on real GDP. For that reason, the study recommends that some expansionary fiscal policy measures should be strengthened since they play a very important role in the economy so as to meet the government target of the National Development Plan Vision for 2030.
\end{abstract}

Keywords: Budget deficit, capital formation, government, tax revenue, South Africa

\section{Introduction}

Fiscal policy ensures macroeconomic stability as a precondition for growth at the macro level. The question of whether or not it encourages growth has been a bone of contention for both theoretical and empirical debates for a long time. Other schools of thought argued that government involvement is vital for its macroeconomic objectives. A contrary view to this holds that government operations are inherently bureaucratic and inefficient in their nature therefore they are likely to stifle rather than to promote any economic growth. In the empirical literature, results are equally mixed about this issue. Those who are in support of fiscal intervention are of the opinion that it enhances growth by modifying work and investment incentives. They also argue that it stimulatesthe human capital accumulation and also improves the total factor productivity at the micro level. In support of this view, Masca et al. (2015) argued that fiscal policies have been used to control the Great economic crisis of the 1930s, as well as the crude oil crisis in the 1970s; but for the 1980s, the monetary policy was preferred for re-establishing growth. Similarly, Djelloul et al. (2014) found a long run connection between fiscal policy and growth. They also established a link of a positive causality between economic growth and fiscal revenues. On the other hand, Adefeso (2010) maintained that fiscal incentives on tax cuts are likely to escalate the economic growth than those centred on the increase of government spending. As for fiscal adjustments, those based on spending cuts and tax are more likely to reduce deficits and debt over gross domestic product (GDP)ratios than those on tax increases.

Despite all these contributions, the rationale is that in most cases the aim of the government intervention by means of tax policy has been to controlboth the receipt and expenditure sides of its budget in order to achieve national aims. That been the case, the reality is that, more often than not, there has beensome cases of wastagessince some spending can be manipulated by politicians. There are alsopossibilities of high levels of mismanagement and corruption among other things. Ajisafe and Folorunso (2002)maintained that incorrect government expenditure, tax policies and large shortfalls have been some of the major reasons for the macroeconomic disequilibrium over the years in the Nigerian economy.These findings seem to compare well with the current growing deficit in South Africa which can be attributed to poor governance in most of the state owned entities.Some of the developing nations such as Turkey and Romania used fiscal policies to react to their economic challenges in several ways. In reaction to a 2009 GDP gap, Mihaela and Özay(2014) pointed out that Romania employed the fiscal restraints. This reaction involved the spending cuts done mainly by cutting down the public sector salaries, a substantialdecrease of government expenditure and also the introduction of lump tax rate known as the minimum tax. On the other hand, Turkey employed the tight fiscal policy which was aiming at reducing the public debt stock as one of the strategies to get out of the crises which stemmed out of the financial markets (Kadir \& Ridvan, 2016).

Similarly, in reacting to a situation of lower growth, the South African administrationintend to apply the same tool. The aim was to use fiscal policy to allow for sustainedspending-led growth and a broader budget deficit. 
Even though this resulted in an augmentedamount of debt on the government, the aim of the whole exercise was to protect the economy from collapsing. According to the South African National Planning Commission (2011), the National Development Plan (NDP) Vision for 2030 elucidate that fiscal policy would be expected to have an important role in directing the speed of growth. The NDP explicitly outlines as how to deal with the key challenges which are likely to arise over the next several decades.

Mihaela and Ozay (2014) indicated that in comparison with the large amount of research work on fiscal stimulus in developed countries, there has been a limited amount of literature on this aspect in developing countries. In addition, Adefeso (2010) argued that little is known aboutthe consequences of fiscal policy on growth and in particular about what is generally known as the fiscal multipliers. This generally refers to how much one dollar of tax cuts or spendingincreases translate to GDP. Furthermore, based on the literature survey, in the context of the Sub-Saharan region, majority of the literature on this issue seem to be concentrated in Nigeria, see (Omitogun and Ayinla, 2007; Appah, 2010; Adefeso, 2010; Audu, 2012; Akanni and Osinowo, 2013; Osuala and Jones, 2014). As far as South Africa is concerned, we came across with very few studies includingOcran (2009) who included both fiscal and monetary policy variables in the vector autoregression (VAR) analysis.Therefore, we seek to contribute to this research gap byemploying a similar approach used by Ocran (2009) but focuses only on the fiscal policy variables. The decisionto focus on fiscal policy rather than monetary policy is based on Masca et al. (2015)who argued that around the 1990s, monetary policy approach has showed its weak points, which brought the fiscal policy into the spotlight. They argued that currently, the fiscal policy approach is presenting the essentialinfluence in order to avoid a massive recession because of itsability to lend support on investments and structural transformations.

Furthermore, the focus on the fiscal policy variables is influenced by the fact that during the financial year 2013/14 the South African government debt as a percent of GDP increased to 46\%from 27\%in the financial year 2008/09 which has led to a raised level of fiscal risks(IMF, 2014). Based on that, thisstudy seeks to contribute to the existing body of literature and to the academia on fiscal policy and economic progress in the South African setting. It is also envisaged to contribute tothe design of fiscal policy programmes which can propel economic performance to achieve the desired levels of development. Therefore, the aim is to examine the impact of fiscal policy on economic growth in South Africa.The preceding section gave the background of the study and its objectives. Section two is devoted to the review of the relevant literature both theoretical and empirical studies. Section three highlights the methodology, the empirical results are presented in section four and finally, conclusions and policy implications are presented in section five.

\section{Literature Review}

The origin of theargumentsof the association between fiscal policy and economic growthis an important debate in both the theoretical and empirical literature. Several theories such as the Solow growth theory, the Classical, Keynesian and the Neo-classical theories where used by several authors to attempt to establish the link between these variables. In order to demonstrate controversies about some of these theories Omitogun and Ayinla (2007) enumerated that Classical school believes that debt dispensed by the government do not normally affect the private sector savings. This argument is based on the believe that fiscal deficit financed by debt crowds-out private sector investment. On the other hand, the Keynesians are of the opinion thata positive connectionexists between deficit financing and investment. The implicationis that fiscal policy is seen as a tool used to overcome fluctuations in the economy. Similarly, the Neoclassical school challenged the position of the Keynesian model on the ground that the way in which the fiscal deficits are financed has the ability to have an influence on the level of consumption, investment and economic growth. Given the controversy in the theoretical framework around this issue, Mankiw (2000) developed a new theory called the Savers-Spenderstheory. It is based on several propositions to explain this relationship. The firstproposition is on temporary tax changes. It proposes that it has a huge impact on the demand for goods and services, hence it proposes that the higher income of spenders received will be affected by higher tax payments or by lower refunds. That been the case, citizens should therefore appreciatethe fact that their lifetime resources were unchanged and they need to protect the income to meet the upward tax liability. Secondly, Mankiw (2000) suggests that additional consumption has a negative effect on investment. This will lead to an upsurge on the marginal product of capital and ultimately reduces the level of growth in the country. The idea is that higher interest rate margin, encourages savers to save more and in that sensethe 
additional spending and higher interest rate margin seem to have a positive influence on levels of growth of the manufacturing part of the economy. The sector will then reduce economic growth especially in cases of developing economies such as South Africa. The last proposition proposes that government debt escalates the steady-state inequality. This proposition is premised on the notion that a higher level of debt is an indication of increased taxation in order to pay interest on debt. As a result, the tax burden will ultimately be carried by the savers and the spenders but the interest will only be carried by savers. It can therefore be deduced that a higher level of debt raises the income and consumption of the savers and lowers the income and consumption of the spenders.

Evidence from the empirical literature suggests that theapplication of fiscal policy in an individual country helps to measure sustainable economic activities. Omitogun and Ayinla (2007) attempted to establish association between fiscal policy and growth in Nigeria by means of the Solow model estimated by the ordinary least square method. Their result proved to be negative in the sense that fiscal policy has not been effective in promoting sustainable growth in Nigeria. These findings were not in line with the Keynesian theory which is based on the need for an active policy to sustain growth. In a similar case, Appah (2010) utiliseda multiple regression analysis as well as the Granger causality test. GDP was used as a proxy for economic growth and the few related fiscal policy variables as the regressors. Contrary to Omitogun and Ayinla (2007), he found a significant association between the two sets of variables but the specific variables contributing to the GDP weremainly government recurrent and capital expenditures. In order to take the investigation further, unlike Appah(2010), Ocran (2009) added monetary variables and inspected the influence of both fiscal and monetary policyon growth in the South Africancontext. He employed thevector autoregression (VAR)approach and his outcome supported the argument that government consumption expenditure, gross fixed capital formation and tax revenue do have a positive and significant influence on the economic performance. However, it appears that the magnitude of the deficit does not have a major effect on growth, which might suggestthat budget deficit does not cause growth rate. Furthermore, Ocran (2009) concluded that the pair-wise combination of the fiscal policy indicators better explains the main influence of fiscal policy on the economic progress of a country. Similarly, Dar and AmirKhalkhali (2002) established that in the endogenous growth model of fiscal policy, government expenditure and income are normally important in forecasting future growth. Finally, Abdullah (2000) established that the scope of government expenditure is crucial in managing the performance of its economy. Based on these findings, he recommended that, each and every administration should not only support and inspire the private sector to fast-track economic growth, but it should also look at the ways of expanding the budget for some of the vital aspects of the economy such as the infrastructure, social and other economic activities.

\section{Methodology}

This study follows a Cointegrated Vector Autoregression (CVAR) method which comprisesof the stationarity testing, the Johansen cointegration and the Vector Error Correction Model (VECM) analyses. In addition, the Pair-Wise correlation matrix and Vector Error Correction (VEC) stability condition check are used for further analysis. The study employed the annual time series data from 1960 to 2014to investigate the impact of fiscal policy on economic growth in South Africa. The choice of this period was influenced by the fact that 2014 was seen as a second decade since the dawn of democracy which was accompanied by a raised level of fiscal risks. This was based on the fact that there was an increase in government debt to $46 \%$ of GDP in the financial year 2013/14 from 27\% of GDP in 2008/09 which has led to a raised level of fiscal risks (IMF, 2014). In order to establish a sensibleamount of observations, the period of study was backdated to 1960 to end up with at least 54 number of observations for the sake of proper econometric analysis. Data on all the variables were obtained from South African Reserve Bank website in billions of Rands. The model is founded on the amendmentof Appah (2010)'s model whichspecifies endogenous real GDP as a function of government fixed capital formation, budget deficit and government tax revenue as follows:

$R G D P=f(G F C F, B D F T, G T R)$

and equation 1 can be expressed as a linearequation as follows:

$R G D P_{t}=\beta_{0}+\beta_{1} G F C F_{t}+\beta_{2} B D F T_{t}+\beta_{3} G T R_{t}+\mu_{t}$

where: 


$\begin{array}{lll}R G D P & = & \text { Real Gross Domestic Product } \\ G F C F & = & \text { Government gross fixed capital formation } \\ \text { BDFT } & = & \text { Budget deficit; } \\ \text { GTR } & = & \text { Government tax revenue }\end{array}$

$\beta_{0}$ is the intercept term which is the mean value of RGDP when the value of all the explanatory variables is zero. $\beta_{1}, \beta_{2}$ and $\beta_{3}$ are the partial regression coefficient as indicated by Gujarati and Porter (2009) and according to Sweeney, et al., (2006), $\mu_{t}$ represents the unexplained variationsof the dependent variable which cannot be accounted for by the linear effect of all the independent variables in the system.

In estimating equation 2, prior to the normal tests, the study employed correlation matrix to check the relationship amongst the variables. In this case, correlation refers to a simple statistic which explains whether there's a relationship between any two variables which might eitherbe positive or negative. A positive connection implies thatthey are moving in the same direction, whilst a negative correlation implies a contradictory movement. A correlation is computed into what is known as the correlation coefficient, which ranges between -1 and +1 and the correlation matrix of $R$ is denotedas follows:

\section{Figure 1: Correlation matrix of $R$}

$$
R=\left[\begin{array}{ccc}
1 & \cdots & r 1 k \\
\vdots & \ddots & \vdots \\
r k 1 & \cdots & 1
\end{array}\right]
$$

Based on Tiwari (2011)'s claim that before performing a static and dynamic investigation, certain preestimations are required. They include tests such as stationarity testing, cointegration and the error correction estimations because without them, conclusions drawn from such analyses are regarded as meaningless. He argued that these tests are conducted with the aim to eradicate the condition of spurious resultsbecause the results from such unauthenticanalysis are pointless in that all errors are permanent. At the end the model will be taken through the vector error correct (VEC) stability condition check to determine the robustness of the results.

\section{Results and Discussion}

This section presents the results, interpretations and the discussions of all the empirical tests conducted in this study.

Correlation matrix: Table 1 presents the results of the Pair-Wise correlation matrix used to determine the nature of the relationship amongst our variables. The results indicate that only GTR is positively correlated with RGDP and the indication is that its high valueis likely to be associated with high value of RGDP in South Africa.

Table 1: Pair-Wise correlation matrix results

\begin{tabular}{lllll}
\hline & RGDP & GTR & GFCF & BDFT \\
\hline RGDP & 1.000000 & 0.898212 & -0.368224 & 0.021230 \\
GTR & 0.898212 & 1.000000 & -0.377380 & 0.082689 \\
GFCF & -0.368224 & -0.377380 & 1.000000 & -0.143838 \\
BDFT & 0.021230 & 0.082689 & -0.143838 & 1.000000 \\
\hline
\end{tabular}

Unit root tests: The study employed both the Augmented Dickey-Fuller (ADF) and Phillip-Perron (PP) unit root tests to determine the presence of a unit root amongst the variables. The two tests examine the null hypothesis against the alternative hypothesis of a unit root. Therefore, the decision rule is that if the test statistic is more negative than the critical valuesthis will be an indication that the series do not have a unit root problem. Table 2presents the results of both the ADF and PP tests respectively. The results indicate that all variables were nonstationary at levels and they became stationary at first difference. This was based on the fact that the $t$-statistics of all the variables became more negative than the critical values at first difference of both tests. 
The analysis of the results show that our variables do have the same order of integration, of order one and they are therefore regarded as I(1) variables. Given these results, the next step is to establish the chance of a long run economic relationship amongst them by means of Johansen cointegration analysis.

Johansen cointegration test: In order to establish the number of cointegrating vectors, we used the trace and the maximum eigenvalue tests. The hypothesis of no deterministic trend and restricted constant was employedin line with the Pantula Principle. The results from Tables 3 and 4reflect that at least one cointegrating equation occurs at $5 \%$ significance level. This was achieved by comparing the trace statics with the critical values of the hypothesised number of cointegration equation at "None"in Table 3 and the null hypothesis of no cointegrating vectors is rejected. The rejection is based on the fact that the trace test statistic of 50.98856 is bigger than the critical value of approximately 47.85613 at $5 \%$ significance level and it is also confirmed by the probability of 0.02 which is less than $5 \%$. Therefore, the null hypothesis of at least one cointegrating vector cannot be overruledsince the test statistic of 23.19715 is smaller than the critical value of 29.79707 .

Table 2: Unit root tests results

\begin{tabular}{lllll}
\hline Variables & RGDP & GTR & GFCF & BDFT \\
\hline ADF test & & & & \\
Level & -0.696657 & -2.684549 & -2.316805 & -3.411416 \\
& $(-3.496960)$ & $(-3.495295)$ & $(-3.498692)$ & $(-3.495295)$ \\
First Difference & $-4.717455^{*}$ & $-7.341967^{*}$ & $-6.101977^{*}$ & $-7.098917^{*}$ \\
& $(-3.496960)$ & $(-3.496960)$ & $(-3.498692)$ & $(-3.498692)$ \\
PP test & & & & \\
Level & -0.308139 & -2.791832 & -1.874476 & -3.353787 \\
& $(-3.495295)$ & $(-3.495295)$ & $(-3.495295)$ & $(-3.495295)$ \\
First Difference & $-4.717455^{*}$ & $-7.341967^{*}$ & $-5.025521^{*}$ & $-7.078962^{*}$ \\
& $(-3.496960)$ & $(-3.496960)$ & $(-3.496960)$ & $(-3.496960)$
\end{tabular}

Note: Critical values are in parenthesis at $5 \%$ the appropriate lag length was selected by adopting the Schwarz info criterion (SIC) for ADF test and Andrews Bandwidth for PP test. Absolute values are not adopted

Table 3: Cointegration Rank Test (Trace) Results

\begin{tabular}{|c|c|c|c|c|}
\hline Hypothesized No. of CE(s) & Eigenvalue & Trace Statistic & 0.05Critical Value & Prob.** \\
\hline None $^{*}$ & 0.408070 & 50.98856 & 47.85613 & 0.0247 \\
\hline At most 1 & 0.182935 & 23.19715 & 29.79707 & 0.2365 \\
\hline At most 2 & 0.146322 & 12.48923 & 15.49471 & 0.1349 \\
\hline At most $3 *$ & 0.074521 & 4.104547 & 3.841466 & 0.0428 \\
\hline
\end{tabular}

Note: Trace test indicates 1 cointegrating eqn(s) at the 0.05 level; *denotes rejection of the hypothesis at the 0.05 level; **MacKinnon-Haung-Michelis (1999) p-values

In Table 4 the maximum eigenvalue examined the null hypothesis of $r$ cointegrating vectors against the alternative hypothesis of $r+1$ cointegrating relations. Therefore, the null hypothesis of no cointegration was rejected onlyat the hypothesised number of cointegration equation of "None" since the Max-Eigen (test) statistic value 27.79142 is greater than 27.58434 with the probability value of 0.04 . 
Table 4: Cointegration Rank Test (Maximum-Eigenvalue) Results

\begin{tabular}{lcccc}
\hline $\begin{array}{l}\text { Hypothesized } \\
\text { No. of CE(s) }\end{array}$ & Eigenvalue & Max-EigenStatistic & 0.05Critical value & Prob.** \\
\hline None ${ }^{*}$ & 0.408070 & 27.79142 & 27.58434 & 0.0471 \\
At most 1 & 0.182935 & 10.70792 & 21.13162 & 0.6764 \\
At most 2 & 0.146322 & 8.384681 & 14.26460 & 0.3409 \\
At most $3 *$ & 0.074521 & 4.104547 & 3.841466 & 0.0428
\end{tabular}

Note: Trace test indicates 1 cointegrating eqn(s) at the 0.05 level; ${ }^{*}$ denotes rejection of the hypothesis at the 0.05 level; **MacKinnon-Haung-Michelis (1999) p-values

In conclusion, we found that the two tests indicate the presence of one cointegrating equation amongst the variables which signifies the presence of a long run relationship amongst them. Since cointegration has been established, the Vector Error Correction Model(VECM)was used to eliminate anyinstability that may shock the system and also to study the interaction among the variables. This model also takes into account an extra channel of causation through the error correction mechanism which helps to determine the dynamic behaviour in the model, that is, the dynamics of both the short and the long run (Hurley, 2010).

Vector error correction model: The VECMs are the elementary Vector Auto Regression (VAR) model, with an error correction term (ECT) fused into the system. The purpose for the infused ECT is to determinethe amount of movement away from the long run equilibrium. The results of the long run analysis are presented in Table 5 as follows;

Table 5: Long run relationship of the VECM

\begin{tabular}{llll}
\hline Variables & Coefficient & Standard-error & t-statistics \\
\hline GTR(-1) & -16.61671 & 0.18685 & -88.9318 \\
GFCF(-2) & 0.906194 & 0.07988 & 11.3444 \\
BDFT(-2) & 13.55028 & 1.02328 & 13.2425 \\
ECT & -0.797428 & 0.36371 & -2.19247 \\
C & 197.5547 & & \\
\hline
\end{tabular}

In order to determine the proper impact of the regressors on the dependent variable, the coefficients from Table 5 are incorporated in the model (equation 2) to form the long run cointegrating equation as follows:

$$
R G D P_{t}=197.5547+16.61671 G F C F_{t}-13.55028 B D F T_{t}-0.906194 G T R_{t}+\mu_{t} \quad 3
$$

In order to be able to establish whether signs of the coefficients of the independent variables from Table 5 are as anticipated or not, they were reversedwhen they were transposed to the right hand side of the equal sign of equation 3. Therefore, the results show thatGTR has a positive and significant long run influence on economic growth whereas the GFCF and BDFT have a negative impact on RGDP.

Table 6: Short run relationship of the VECM

\begin{tabular}{|c|c|c|c|c|}
\hline Variables & & icient & Standard-error & t-statistics \\
\hline GTR(-1) & \multicolumn{2}{|c|}{-8.991899} & 4.90360 & -1.83374 \\
\hline GFCF $(-2)$ & \multicolumn{2}{|c|}{2.138597} & 0.80602 & 2.65327 \\
\hline BDFT(-2) & \multicolumn{2}{|c|}{9.684297} & 3.51238 & 2.75719 \\
\hline ЕСТ(CointEq1) & \multicolumn{2}{|c|}{-0.797428} & 0.36371 & -2.19247 \\
\hline $\mathrm{R}^{2}$ & 0.876816 & S.E equation & 3.348881 & \\
\hline Adj R-squared & 0.470309 & F-statistic & 2.156951 & \\
\hline
\end{tabular}

Furthermore, the results of the short run relationship in Table 6 showthat as expected, the ECT (-0.797428) has a negative sign in line with the theory. The implication is that the system will be able to come back to equilibrium at a much higher rate of 0.797428 which translates into about $80 \%$ speed of adjustment back to equilibrium. Finally, the results of the VEC stability condition check with the inverse roots of the AR 
characteristic polynomialare illustrated in Figure 2. Since there is no root outside the unit circle, it implies that the VECM model fulfils the stability condition and it is therefore deemed acceptable in a statistical sense(Agung, 2011).

\section{Figure 2: Inverse Roots of AR Characteristic Polynomial}

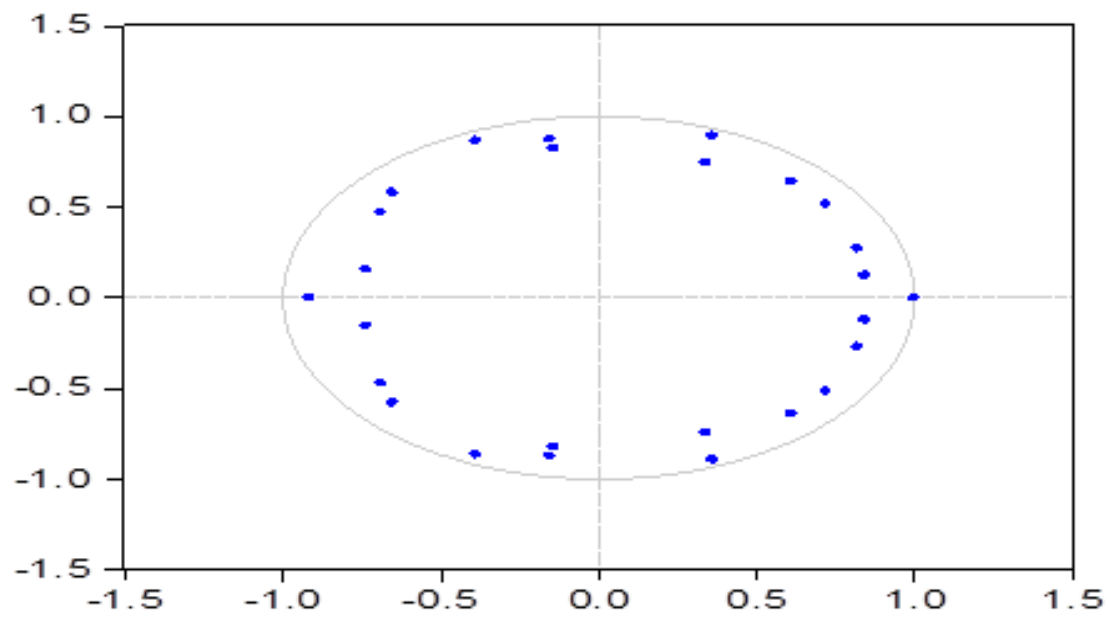

\section{Conclusion and Recommendations}

The purpose of this analysis was to investigate the impact of fiscal policy on economic growth by employing annual time series data from 1960 to 2014. The Pair-Wise correlation matrix results indicate that only GTR is positively correlated with RGDP and its higher value is likely to be associated with high value of RGDP.The unit root tests results revealed that our variables are all integrated of order one. Furthermore, the presence of the long run economic relationship amongst fiscal policy and economic growth was established by means of Johansen cointegration analysis. This is in line withDjelloul, et al., (2014) who discovered the presence of a long run relationship between fiscal variables and growth in the MENA countries (Algeria, Egypt, Jordan, Iran, Tunisia, Morocco, Bahrain, Oman, Kuwait). The long run estimates indicate that government tax revenue has a positive and significant long run effect on economic growth and the government gross fixed capital formation and budget deficit have a negative impact on RGDP. Finally, the results are inconsistent with Osuala and Jones (2014) who found out that budget deficit has no major impact on RGDP growth in Nigeria and at the same time in line Ocran (2009) who also established a positive association between government tax revenue and economic growth in the South African economy. The negative coefficient of ECT indicates that in the short run the system will be able to come back to equilibrium at about $80 \%$ speed of adjustment. The robustness of the results was determined by the model which satisfies the stability condition. Henceforth, the study recommends that some expansionary fiscal policy measures should be strengthened as they play a very important role in the economy so as to meet the government target of the NDP of 2030.

\section{References}

Abdullah, H. (2000). The Relationship between Government Expenditure and Economic Growth in Saudi Arabia. Journal of Administrative Science, 12(2), 173-191.

Adefeso, H. M. (2010). The Fiscal-Monetary Policy and Economic Growth in Nigeria: Further Empirical Evidence. Pakistan Journal of Social Sciences, 7(2), 137-142.

Agung, I. G. (2011). Time series data analysis using EViews. New York: John Wiley \& Sons.

Ajisafe, R. \& Folorunso, B. (2002). The Relative Effectiveness of Fiscal and Monetary Policy in Macroeconomic Management in Nigeria. The African Economic and Business Review, 3(1), 23-40.

Akanni, K.\& Osinowo, O. (2013). Effect of Fiscal Instability on Economic Growth in Nigeria. Advances in Economics and Business, 1(2), 124-133.

Appah, E. (2010). The Relationship between fiscal policy and Economic growth in Nigeria (1991-2005). International Journal of Economic Development Research and Investment, 1(2), 14-18. 
Audu, N. P. (2012). The Impact of Fiscal Policy on the Nigerian Economy. International Review of Social Sciences and Humanities, 4(1), 142-150.

Dar, A. \& AmirKhalkhali, S. (2002). Government size, factor accumulation, and economic growth: evidence from OECD countries. Journal of Policy Modeling, 24(8), 679-692.

Djelloul, D., Rouaski, K., Toumache, R.\& Talbi, B. (2014). The impact of fiscal policy on economic growth: Empirical evidence from panel estimation.The 2014 WEI International Academic Conference Proceedings (pp. 1-8). New Orleans: The West East Institute.

Gujarati, D. N. \& Porter, D. C. (2009). Basic Econometrics. Boston: Mcgraw Hill International Edition.

Hurley, D. (2010). A generalized impulse response investigation of U.S. long and short-term interest yields and Asian holdings of U.S. treasuries. Journal of International and Global Economic Studies, 3(1), 6886.

IMF. (2014). South Africa: Staff report for the 2014 Article IV consultation. Washington, D.C.: International Monetary Fund.

Kadir, K. \& Ridvan, K. (2016). Impact of Fiscal Policy on the Macroeconomic Aggregates in Turkey: Evidence from BVAR Model. Istanbul Conference of Economics and Finance.38, pp. 408 - 420. Istanbu: Procedia Economics and Finance.

Mankiw, N. G. (2000). The Savers-Spenders Theory of Fiscal Policy.American Economic Review, 90(2), 120125.

Masca, S. G., Cuceu, I. C. \& Vaidean, V. L. (2015). The Fiscal Policy as Growth Engine in EU countries. Procedia Economics and Finance, 32, $1628-1637$.

Mihaela, G. \& Özay, Ö. (2014). An Empirical Study on Fiscal Policy in crises time: Evidence from Romania and Turkey. Emerging Markets Queries in Finance and Business Conference, 15, 975 - 984. Bucharest: Procedia Economics and Finance.

National Planning Commission. (2011). Diagnostic Overview. The Presidency. Pretoria: Republic of South Africa. Retrieved from www.npconline.co.za

Ocran, M. K. (2009). Fiscal Policy and Economic Growth in South Africa. Conference on Economic Development in Africa (pp. 1-23). Oxford: St. Catherine's College, Oxford University.

Omitogun, O. \& Ayinla, T. A. (2007). Fiscal Policy and Nigerian Economic Growth: Open Economy. IMF Working Paper(500P).

Osuala, A.\& Jones, E. (2014). Empirical analysis of the fiscal policy on economic growth of Nigeria. International journal of economics and finance, 6(6), 203-211.

Parkin, M., Powell, M. \& Matthews, K. (2008). Economics (7th ed.). London, United kingdom: Pearson Education Limited.

Sweeney, D. L., Williams, T. A. \& Anderson, D. R. (2006). Fundamentals of Business Statistics. Tax laws in Nigeria. International Student Edition Thomson South-Western.

Tiwari, A. K. (2011). Energy consumption, CO2 emissions and economic growth: A revisit of the evidence from India. Applied Econometrics and International Development, 11(2), 165-189. 